\title{
Optical Blade Position Tracking System Test
}

\section{Technical Report} NREL/TP-500-39253 January 2006

\author{
L.J. Fingersh
}

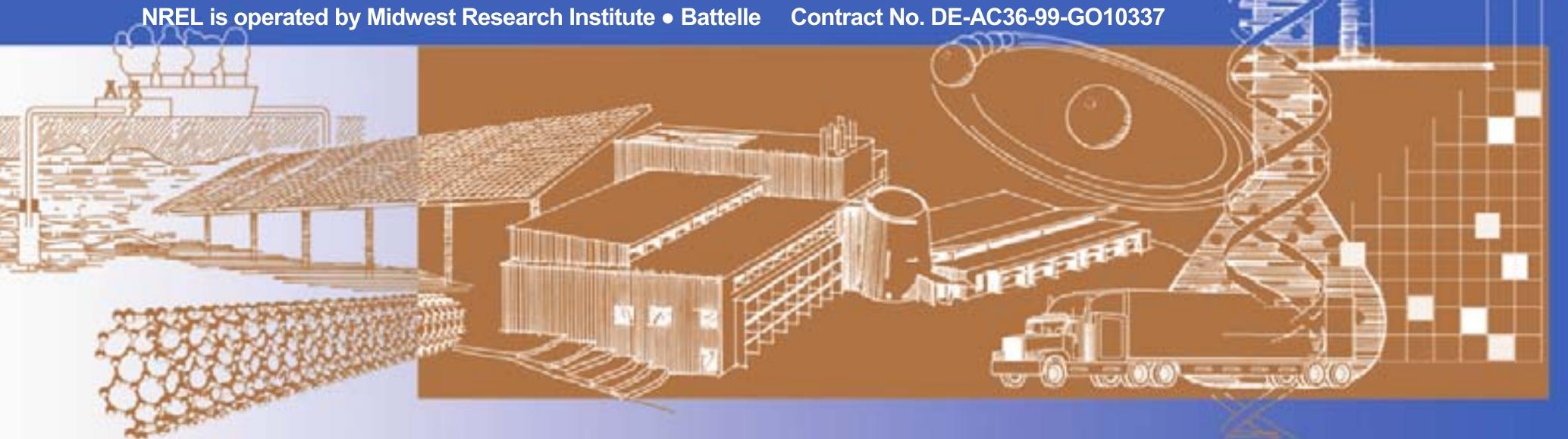




\section{Optical Blade Position Tracking System Test}

\section{Technical Report NREL/TP-500-39253 January 2006}

\section{L.J. Fingersh}

Prepared under Task No(s). CP05.3001

National Renewable Energy Laboratory 1617 Cole Boulevard, Golden, Colorado 80401-3393 303-275-3000 • www.nrel.gov

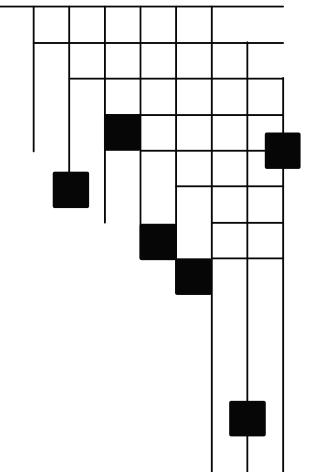




\section{NOTICE}

This report was prepared as an account of work sponsored by an agency of the United States government. Neither the United States government nor any agency thereof, nor any of their employees, makes any warranty, express or implied, or assumes any legal liability or responsibility for the accuracy, completeness, or usefulness of any information, apparatus, product, or process disclosed, or represents that its use would not infringe privately owned rights. Reference herein to any specific commercial product, process, or service by trade name, trademark, manufacturer, or otherwise does not necessarily constitute or imply its endorsement, recommendation, or favoring by the United States government or any agency thereof. The views and opinions of authors expressed herein do not necessarily state or reflect those of the United States government or any agency thereof.

Available electronically at http://www.osti.gov/bridge

Available for a processing fee to U.S. Department of Energy and its contractors, in paper, from:

U.S. Department of Energy

Office of Scientific and Technical Information

P.O. Box 62

Oak Ridge, TN 37831-0062

phone: 865.576 .8401

fax: 865.576 .5728

email: mailto:reports@adonis.osti.gov

Available for sale to the public, in paper, from:

U.S. Department of Commerce

National Technical Information Service

5285 Port Royal Road

Springfield, VA 22161

phone: 800.553 .6847

fax: 703.605.6900

email: orders@ntis.fedworld.gov

online ordering: http://www.ntis.gov/ordering.htm 


\section{Introduction}

As wind turbines have grown larger, their structures have grown softer and more highly optimized. As a result, wind turbine controls are now seen as a viable way of reducing structural loads on wind turbines and therefore reducing the amount of material needed to withstand the resulting stresses. One problem with using such advanced controls is that they need inputs. The inputs that work best are those closest to the forces applying the loads to the structure. On a wind turbine, those are aerodynamic forces applied to the blades. Unfortunately, systems designed to measure those forces directly are expensive and unreliable and are therefore very unlikely to be deployed onto commercial machines.

The alternative described in this paper is to measure the blade deflection along the span of the blade. It has long been known that this is a very good input source for advanced controls. The problem is in obtaining a blade deflection signal in a cost-effective and reliable manner. This paper proposes the use of simple off-the-shelf infrared security cameras along with blade-mounted retro-reflective tape and video image processing hardware and software to obtain these measurements.

\section{System}

The system proposed is extremely simple and easy to implement. All one must do is to

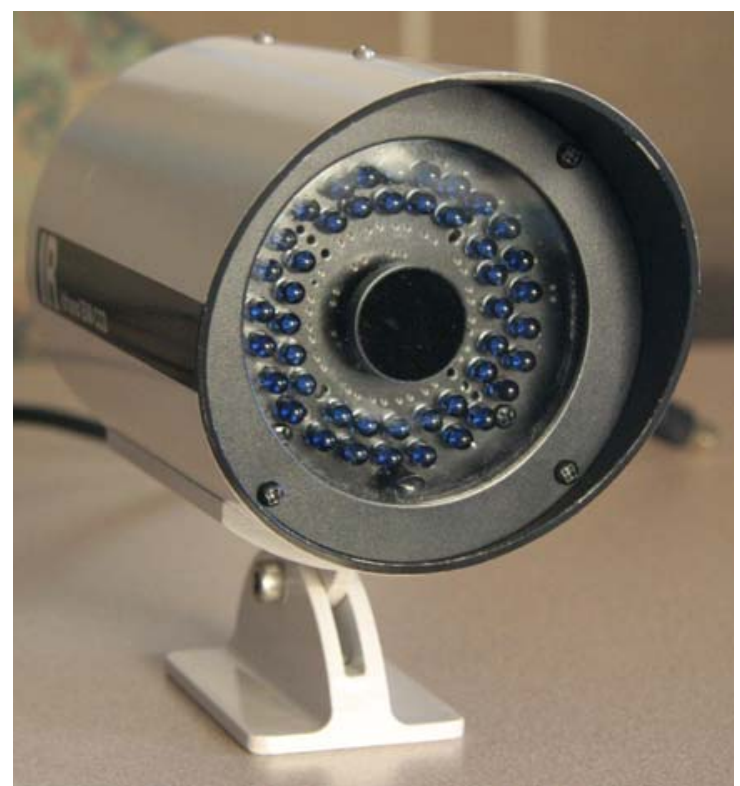

Figure 1. Security camera with infrared emitter and IR filter mount small tabs along the blade, preferably along the trailing edge, each with a small amount of highly-selective retro-reflective tape facing the blade root. A security camera containing infrared emitters (Figure 1) is then mounted at a position near the root of the blade such that it can see the tabs. The infrared light from the emitters is bounced straight back to the camera via the tape. The camera can observe the location of the tape and the image can be captured by video capture hardware. Through calibration, the location of the tape, and hence the blade, can be determined.

The camera used has been modified with the addition of an infrared filter over the lens.

This filter has its center frequency at the frequency of the IR LEDs. This filter is designed to filter out all other wavelength except those that come from the infrared LED light reflected back by the tape. Unfortunately, clouds also emit this frequency when illuminated by sunlight. It is hoped that the IR tape is brighter than the clouds and the clouds can be filtered out by luminance 
value at the processing stage. Initial testing indicated this might be the case, but this result has yet to be validated.

\section{Testing}

In order to determine the feasibility of this system, a simple test was performed. A static blade test was performed (Figure 2) and the testing involved string-potentiometers designed to measure deflection at three locations along the blade. This represented an opportunity to check the performance of the optical system against a known reference.

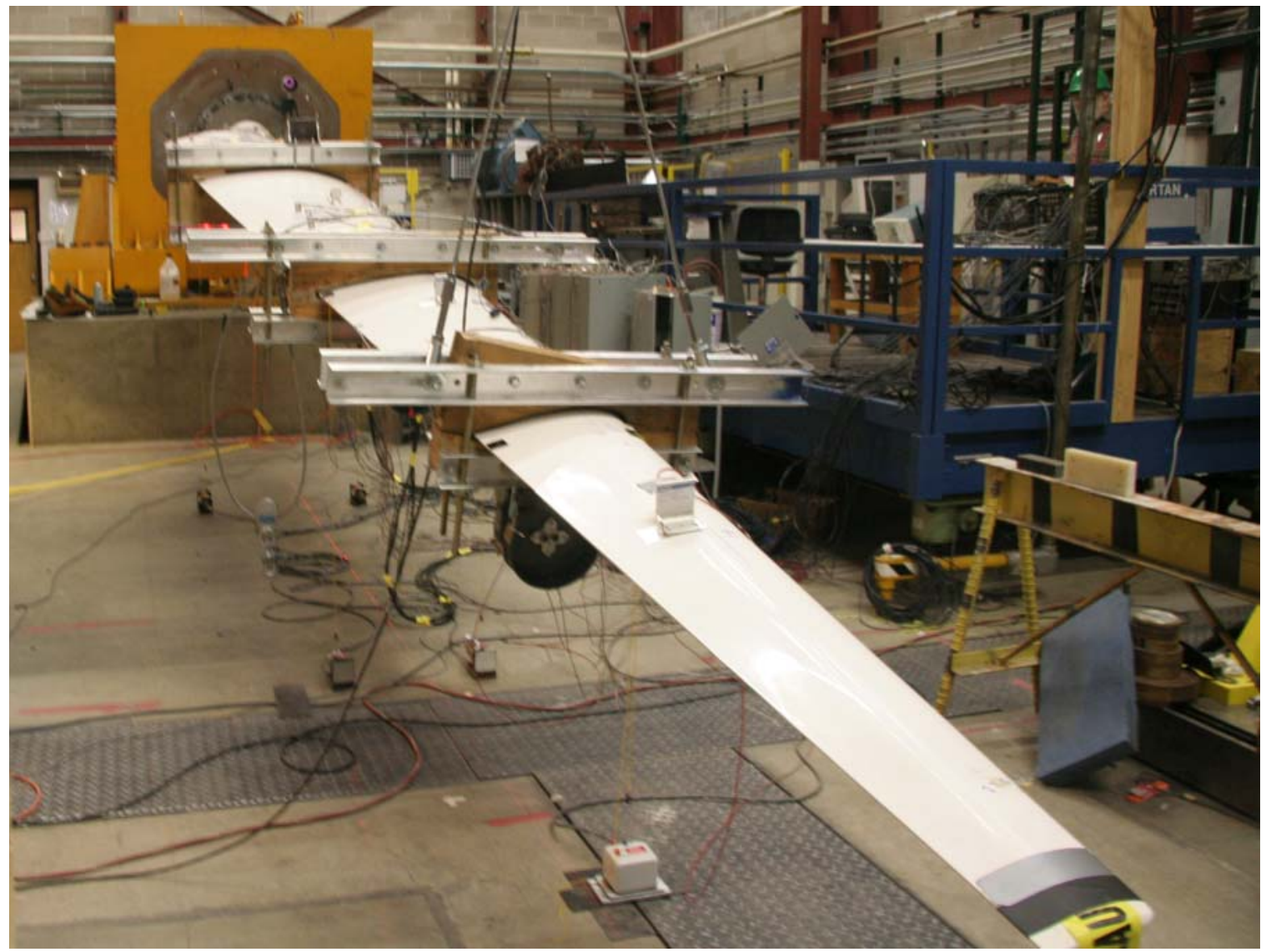

Figure 2. Blade static test 
The camera was set up and tape was applied to the three load saddles (Figure 3). The bolt will be addressed later. One complication of the test was that the stringpotentiometers were not located at the saddle locations but were instead located nearby. This resulted in the need to adjust one data set to the other in order to determine if the data were consistent.

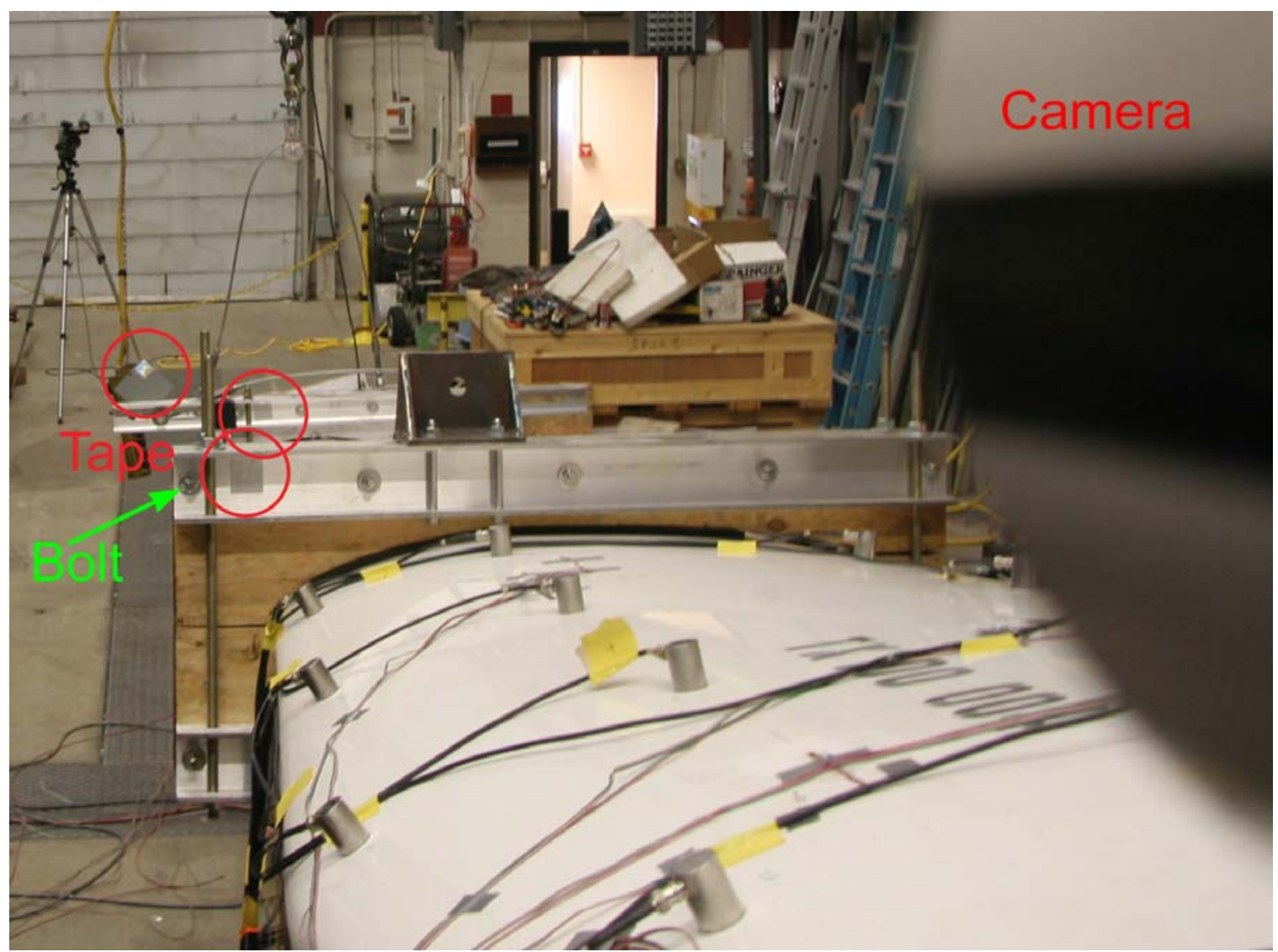

Figure 3. Camera, tape, and bolt locations 
Calibrations were performed very simply by holding a large ruler next to the measurement locations. Video was captured during this process and frames were analyzed later. One such frame is in Figure 4. The frame was analyzed to determine the length of the ruler in pixels. Combining this information with the known length of the ruler (18 inches in this case) led to a calibration of pixels/inch at each station. The bright squares at the top are lens flare and the speckles around the frame are hot pixels. Both can be eliminated quite easily in several ways. We intend to remove most of the flare by reducing the image exposure and the hot pixels by a method called "dark-frame subtraction" in which a frame is captured in the dark and that frame is subtracted from all future frames.

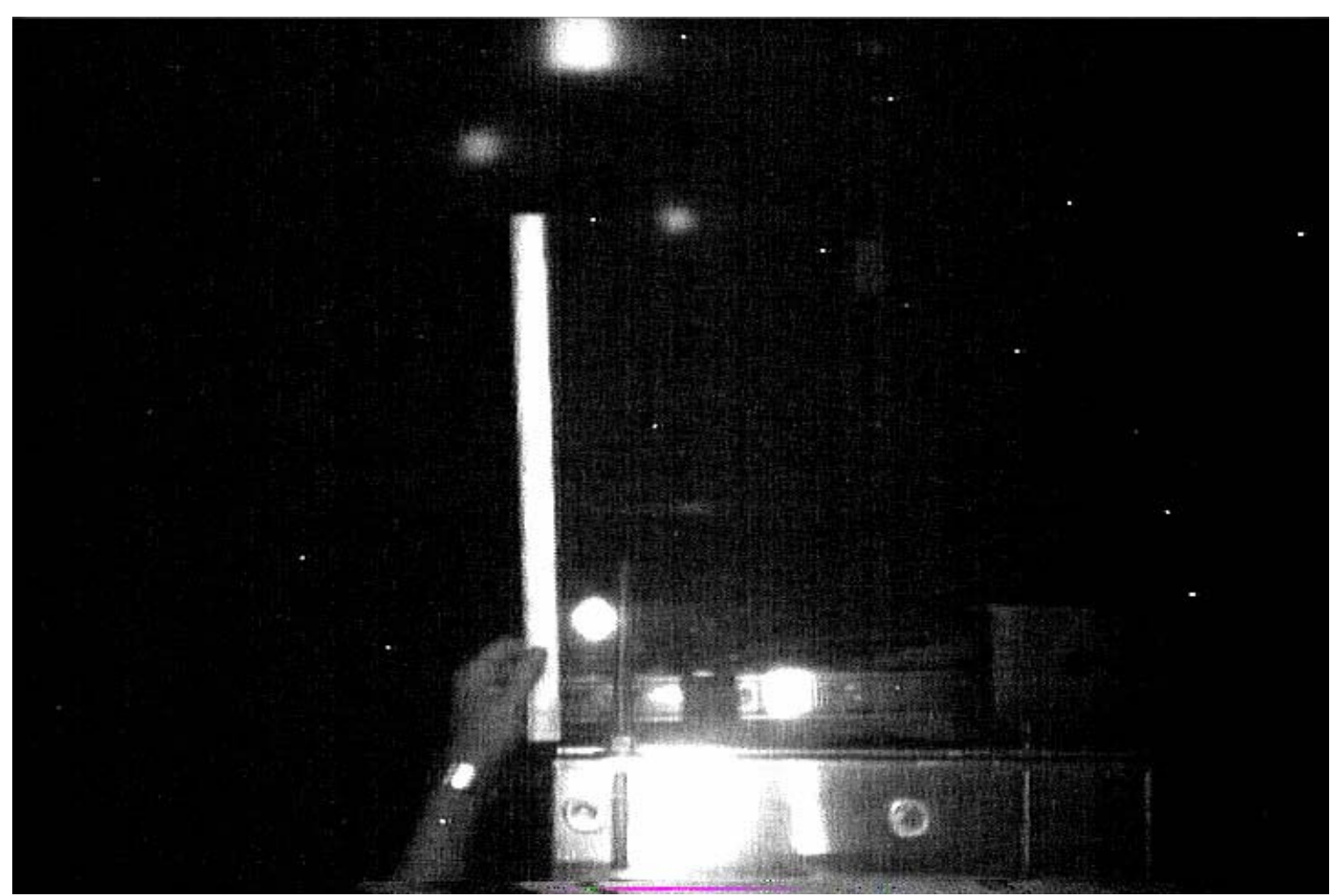

Figure 4. Example calibration frame 
Once calibrations were complete, the test was begun. At the completion of the test, frames were captured from the video at each load point and analyzed. Once such frame is in Figure 5.

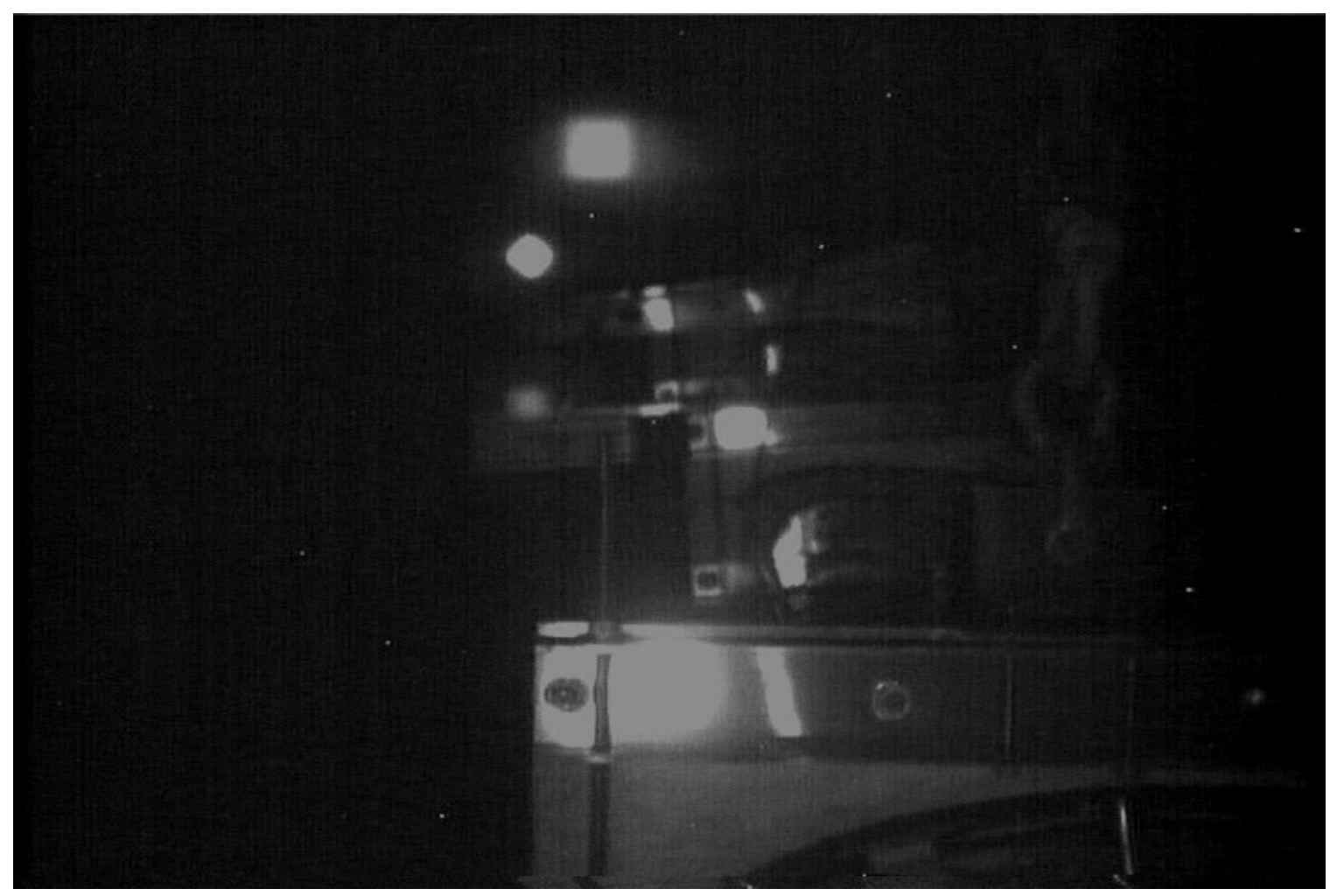

Figure 5. Example load frame

The overexposure of the first tape location can be avoided using one of several approaches (reducing gain, masking, etc.) but, for this test, the bolt to the left of the tape was used instead. For the other two locations, the center of the tape was used as the measurement location. All of the data were analyzed and compared to the output of the string-potentiometers.

\section{Results}

The test results are shown graphically in Figure 6. The results of the test indicated the optical system had a mean error of $1.1 \%$, and a median error of $1.6 \%$. The standard deviation of the errors was $3 \%$, and the errors of the extremes were $-6.2 \%$ and $+4.1 \%$. Some of these errors were caused because the string potentiometers were not measuring the same thing as the optical system. The string system measured deflection in two directions while the optical system only measured in one. Also, the measurements were not in the same radial or chord-wise location but were only adjusted for radial location. Overall the optical system performed very well. 


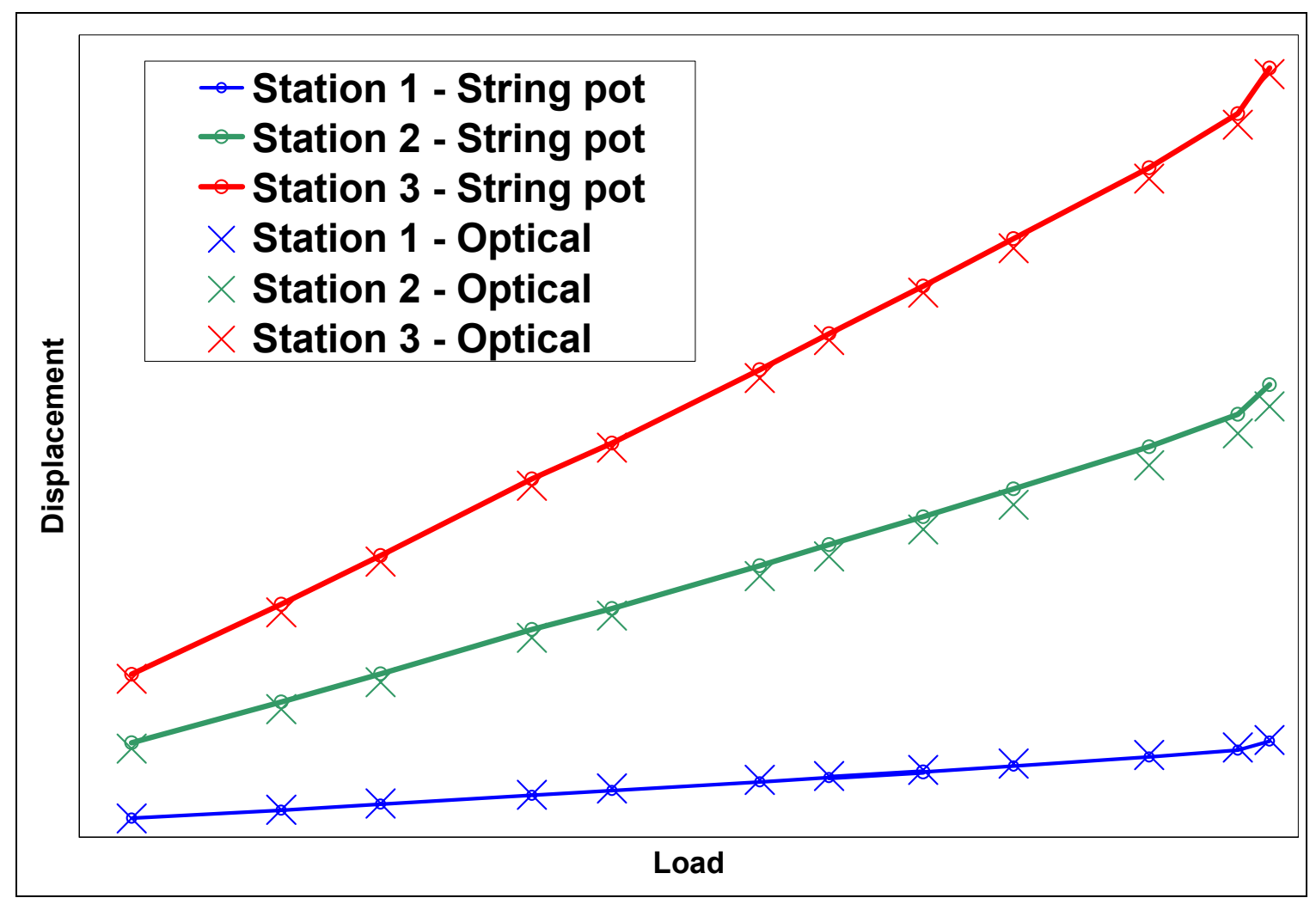

Figure 6. Test results

One big benefit to this system over other systems for measuring blade deflection is that it is inherently continuous and multi-point. In fact, with an interleaved camera, it is possible to extract 60 new frames per second for analysis at three or more points along the blade span. The system is also very inexpensive, highly reliable, and readily available. Possible drawbacks include the need for video capture hardware and processing software, though, in many cases these can also be obtained quite inexpensively. Another possible drawback is interference from the sun or from clouds. Finally, it is not known how well this system will perform in snow, fog, or icing conditions.

In the event there are dropouts from the system, it may be possible to control the turbine loads anyway. With estimators, there is likely to be a loss of performance but it is equally likely that turbine shutdown will not be required. There are many approaches to increasing robustness in control design and many of them are applicable to this system.

\section{Conclusion and Future Plans}

The optical system was set up very easily and quickly and yet performed very well. We now intend to put the system on the CART 3 turbine that is currently being installed at the National Wind Technology Center for controls research. The cameras will be interfaced with real-time video processing hardware and software and integrated into the control system. 


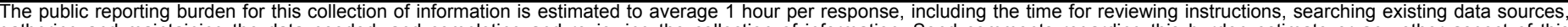

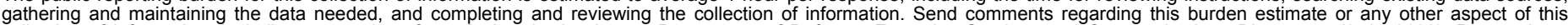

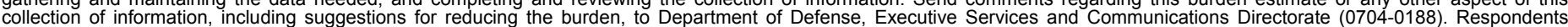

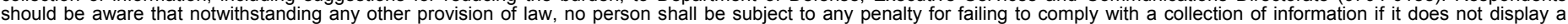

currently valid OMB control number

PLEASE DO NOT RETURN YOUR FORM TO THE ABOVE ORGANIZATION.

\begin{tabular}{l|l|l|l} 
1. REPORT DATE (DD-MM-YYYY) & 2. & REPORT TYPE & 3. DATES COVERED (FrOm - TO)
\end{tabular} January 2006

technical report

4. TITLE AND SUBTITLE
Optical Blade Position Tracking System Test

5a. CONTRACT NUMBER

DE-AC36-99-G010337

5b. GRANT NUMBER

5c. PROGRAM ELEMENT NUMBER

6. AUTHOR(S)

L.J. Fingersh

5d. PROJECT NUMBER

NREL/TP-500-39253

5e. TASK NUMBER

WER6.2106

5f. WORK UNIT NUMBER

7. PERFORMING ORGANIZATION NAME(S) AND ADDRESS(ES)

National Renewable Energy Laboratory

1617 Cole Blvd.

8. PERFORMING ORGANIZATION REPORT NUMBER

Golden, CO 80401-3393

NREL/TP-500-39253

9. SPONSORING/MONITORING AGENCY NAME(S) AND ADDRESS(ES)

10. SPONSOR/MONITOR'S ACRONYM(S)

NREL

11. SPONSORING/MONITORING AGENCY REPORT NUMBER

12. DISTRIBUTION AVAILABILITY STATEMENT

National Technical Information Service

U.S. Department of Commerce

5285 Port Royal Road

Springfield, VA 22161

13. SUPPLEMENTARY NOTES

14. ABSTRACT (Maximum 200 Words)

Wind turbine controls are a viable way of reducing structural loads on large wind turbines, therefore reducing the amount of material needed to withstand the resulting stresses. Advanced controls need inputs on the forces applying the loads to the structure. On a wind turbine, those are aerodynamic forces applied to the blades. Systems designed to measure those forces directly are expensive and unreliable. This paper proposes the use of simple offthe-shelf infrared security cameras along with blade-mounted retro-reflective tape and video image processing hardware and software to obtain wind turbine blade deflection measurements along the span of the blade.

15. SUBJECT TERMS

wind turbine control systems; load measurement; blade deflection measurements; infrared camera

16. SECURITY CLASSIFICATION OF:
\begin{tabular}{|l|l|l|}
\hline $\begin{array}{l}\text { a. REPORT } \\
\text { Unclassified }\end{array}$ & $\begin{array}{c}\text { b. ABSTRACT } \\
\text { Unclassified }\end{array}$ & $\begin{array}{l}\text { c. THIS PAGE } \\
\text { Unclassified }\end{array}$ \\
\hline
\end{tabular}

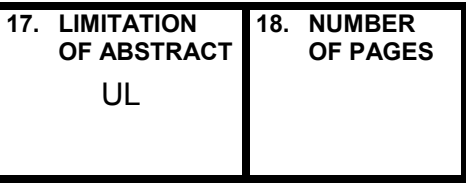

19a. NAME OF RESPONSIBLE PERSON

19b. TELEPHONE NUMBER (Include area code) 